\title{
AFLP fingerprinting: an efficient technique for detecting genetic variation of Xanthomonas axonopodis pv. manihotis
}

\author{
Silvia Restrepo, ${ }^{1}$ Myriam Duque, ${ }^{1}$ Joe Tohme ${ }^{1}$ and Valérie Verdier ${ }^{1,2}$
}

Author for correspondence: Valérie Verdier. Tel: +5724450037 Fax: +5724450073.

e-mail: v.verdier@)cgnet.com

1 Biotechnology Unit, Centro Internacional de Agricultura Tropical (CIAT), AA 6713, Cali, Colombia

2 Institut Français de Recherche Scientifique pour le Développement en Coopération (ORSTOM), Genetrop, Unité de Phytopathologie, BP5045, 34032 Montpellier, France

\begin{abstract}
Xanthomonas axonopodis pv. manihotis (Xam) is the causative agent of cassava bacterial blight (CBB), a worldwide disease that is particularly destructive in South America and Africa. CBB is controlled essentially through the use of resistant varieties. To develop an appropriate disease management strategy, the genetic diversity of the pathogen's populations must be assessed. Until now, the genetic diversity of Xam was characterized by RFLP analyses using ribotyping, and plasmid and genomic Xam probes. We used AFLP (amplified fragment length polymorphism), a novel PCR-based technique, to characterize the genetic diversity of Colombian Xam isolates. Six Xam strains were tested with 65 AFLP primer combinations to identify the best selective primers. Eight primer combinations were selected according to their reproducibility, number of polymorphic bands and polymorphism detected between Xam strains. Forty-seven Xam strains, originating from different Colombian ecozones, were analysed with the selected combinations. Results obtained with AFLP are consistent with those obtained with RFLP, using plasmid DNA as a probe. Some primer combinations differentiated Xam strains that were not distinguished by RFLP analyses, thus AFLP fingerprinting allowed a better definition of the genetic relationships between Xam strains.
\end{abstract}

Keywords: AFLP, DNA fingerprinting, genetic diversity, pathogen population study

\section{INTRODUCTION}

Xanthomonas axonopodis pv. manihotis (Xam) is the causal agent of cassava bacterial blight (CBB), a particularly destructive disease of cassava in South America and Africa. Under favourable conditions, yield losses can reach $80 \%$ after three cycles of vegetative propagation (Lozano, 1986). Furthermore, CBB has caused more damage to the crop than any other cassava disease (Lozano, 1986). The use of resistant cultivars is the principal means of control (Lozano, 1986), but effective breeding for resistance depends on information on the diversity and genetic structure of pathogen populations. Because of the broad range of conditions under which cassava is cultivated, the cassava production regions were divided into edaphoclimatic zones (ECZs). These were defined according to the importance

Abbreviations: AFLP, amplified fragment length polymorphism; CBB, cassava bacterial blight; ECZ, edaphoclimatic zone; $\mathrm{Ht}$, genetic diversity index; MCA, multiple correspondence analysis; Xam, Xanthomonas axonopodis pv. manihotis. of the agro-ecosystem for cassava production, climatic conditions, predominant soil type, and pest and disease problems. Seven zones exist: ECZ1, subhumid tropics; ECZ2, acid-soil savannas; ECZ3, humid tropical lowlands; ECZ4, mid-altitude tropics; ECZ5, high-altitude tropics; ECZ6, subtropics; ECZ7, semi-arid tropics.

To assess the genetic diversity of Xanthomonas pathogens, the following techniques have been used extensively: RFLP, for the study of Xanthomonas oryzae pv. oryzae (Leach et al., 1992); random amplified polymorphic DNA (RAPD) (Smith et al., 1994) and ribotyping (Berthier et al., 1993) to study diversity among different pathovars of Xanthomonas campestris; repPCR fingerprinting for the characterization of Xanthomonas campestris pv. vesicatoria (Louws et al., 1995); and polymorphism of amplification of rDNA spacer sequences to determine the relatedness between $X$ anthomonas pathogens that cause cereal leaf streak (Maes $e t$ al., 1996).

Until recently, the genetic diversity of Xam was mainly characterized by RFLP analyses, using the pathogenicity gene $(p t h \mathrm{~B})$ as the RFLP probe (Restrepo \& Verdier, 
1997; Verdier et al., 1993). This technique is more precise and discriminative than those of RFLP analyses using genomic probes (pBS6 and pBS8) or ribotyping (Restrepo \& Verdier, 1997; Verdier et al., 1993). The genetic variability of Xam was pronounced in strains from South America but was limited in strains from other regions (Verdier et al., 1993). The analysis of Colombian Xam populations, collected from different ecological zones, showed the existence of at least one clonal population (Restrepo \& Verdier, 1997), which was found in the high-altitude tropics. To verify the genetic homogeneity of this population, we needed a molecular technique that can detect smaller sequence variations than can the RFLP technique. Moreover, the sequences with which the pathogenicity gene ( $p t h \mathrm{~B})$ hybridizes have the major disadvantage of representing a minute portion of the genome, containing genes that are subject to strong natural selection (Leung et al., 1993). To avoid possible bias, the population structure should be inferred from neutral markers that distribute randomly throughout the genome (Janssen \& Dijkshoorn, 1996).

Amplified restriction fragment length polymorphism (AFLP) is a recently developed technique for the fingerprinting of plant, bacterial, fungal and nematode genomes (Folkerstma et al., 1996; Lin et al., 1996; O'Neill et al., 1997; Vos et al., 1995). The advantages (Dijkshoorn et al., 1996; Janssen et al., 1996; Lin et al., 1996) of this technique in characterizing microbial populations are the extensive coverage of the genome under study (Janssen et al., 1996) and that the complexity of the AFLP fingerprint can be advantageously managed by adding selective bases to the primers during PCR amplifications (Vos et al., 1995). For the bacterial genome, the AFLP method has been evaluated in microbial taxonomy (Vaneechoutte, 1996), in diversity studies of human pathogenic bacteria (Huys et al., 1996; Picardeau et al., 1997), and in characterizing plantpathogenic bacteria at the pathovar level (Bragard et al., 1997). Janssen et al. (1996) also demonstrated the high resolution of AFLP in characterizing bacterial strains at the subgeneric level. However, until now, AFLP has not been applied to population studies of plant-pathogenic bacteria at the pathovar level.

The objective of this study was to ascertain the usefulness of the AFLP technique in assessing the genetic diversity of Xam at the infrapathovar level. We aimed to establish the appropriate conditions for applying the technique to the study of a Xam population.

\section{METHODS}

Bacterial strains and DNA isolation. We used 46 field isolates collected in Colombia in 1995 and 1996 and one reference strain, CIAT1121 (Table 1). The geographical origin, year of collection, ECZ from where strains were isolated and haplotype for each Xam strain are described in Table 1. Strains were grown on YPG medium, composed of 5 g yeast extract $\mathrm{l}^{-1} ; 5 \mathrm{~g}$ glucose $\mathrm{l}^{-1} ; 5 \mathrm{~g}$ bacto peptone $\mathrm{l}^{-1} ; 15 \mathrm{~g}$ agar $\mathrm{l}^{-1}$. For DNA extraction, the bacteria were grown overnight on a rotary shaker in medium containing peptone $\left(10 \mathrm{~g} \mathrm{l}^{-1}\right)$, casamino acids $\left(1 \mathrm{~g} \mathrm{l}^{-1}\right)$ and yeast extract $\left(1 \mathrm{~g} \mathrm{l}^{-1}\right)$ at $\mathrm{pH} 7 \cdot 2$. Genomic DNA was extracted by the method of Boucher et al. (1985).

AFLP reactions. AFLP markers were assayed as previously described by Vos et al. (1995), with the following modifications: $500 \mathrm{ng}$ DNA was digested in $50 \mu \mathrm{l}$ with four combinations of enzymes (EcoRI/MseI, EcoRI/TaqI, PstI/MseI and PstI/TaqI), then ligated to the respective adapters. Five microlitres of the ligation reaction was amplified for 35 cycles at $94^{\circ} \mathrm{C}$ for $30 \mathrm{~s}, 55^{\circ} \mathrm{C}$ for $30 \mathrm{~s}$ and $72{ }^{\circ} \mathrm{C}$ for $60 \mathrm{~s}$. The PCR product was diluted 20 -fold and $5 \mu$ of the dilution was used for the second amplification, using the same primers as in the first amplification. This PCR reaction was performed with the touch-down PCR thermal profile, with the initial annealing temperature of $60^{\circ} \mathrm{C}$ and subsequent reduction by $1{ }^{\circ} \mathrm{C}$ per cycle to $55^{\circ} \mathrm{C}$. The remaining 30 cycles were as described for the first amplification. Amplifications were done at least twice for each strain.

After completing the second amplification, $3 \mu$ l Stop Solution (Pharmacia Biotech) was added to $5 \mu \mathrm{l}$ reaction mixture. Mixtures were heated for $3 \mathrm{~min}$ at $95^{\circ} \mathrm{C}$ and chilled on ice. Four microlitres of each mixture was loaded onto the gel. The amplified products were separated on a $6 \%$ polyacrylamide denaturing gel on a Sequi-Gen (Bio-Rad) sequencing apparatus. Electrophoresis was carried out for $90 \mathrm{~min}$ for the EcoRI/TaqI primer combination and $2 \mathrm{~h}$ for the other combinations in $1 \times$ TBE buffer $(100 \mathrm{mM}$ Tris, $100 \mathrm{mM}$ boric acid, $2 \mathrm{mM}$ EDTA) at $40 \mathrm{~V} \mathrm{~cm}^{-1}$ and $45^{\circ} \mathrm{C}$. Gels were covered with Saran Wrap, transferred to Whatman 3 MM chromatography paper, dried under vacuum for $1 \mathrm{~h}$ at $80^{\circ} \mathrm{C}$ and exposed to X-ray film for $16 \mathrm{~h}$.

The number and nature of selective nucleotides can modify the complexity of the fingerprint. To identify the best selective primers, tests were conducted on six Xam strains (CIO-1, CIO-46, CIO-90, CIO-298, CIO-299, and CIO-300) with 64 primer combinations, using all 16 possible combinations of $+1 /+1$ primer combinations for each pair of enzymes and an additional combination, Pst $+\mathrm{GG} / \mathrm{Mse} \mathrm{I}+\mathrm{G}$. These strains were collected in ECZs 1, 2 and 5, and belong to different RFLP-pthB haplotypes. The entire set of 47 strains (Table 1) was then analysed, using the eight selected combinations of primers.

The reproducibility of AFLP was assessed by comparing the fingerprinting obtained from duplicate assays of six strains based on all primer combinations. Duplicate AFLP fingerprints were produced using two aliquots of one AFLP-PCR reaction that was run in different gels. A molecular mass standard (aflp 30-330 bp DNA Ladder, Gibco Life Technologies) was used to determine band size.

Data analysis. AFLP markers were used from eight primer combinations and were scored as either present (1) or absent (0). Only strong bands were scored, faint bands were discarded. We used NTSYS-PC (version 1.80; Rohlf, 1994) to calculate a similarity matrix, using Jaccard's coefficient of similarity. Cluster analysis was done with the unweighted pair group arithmetic mean method in the SAHN program of NTSYS-PC. A dendrogram was constructed with the TREE option. A correlation index was calculated between the similarity matrices resulting from AFLP and RFLP, using the $p t h \mathrm{~B}$ probe (Restrepo \& Verdier, 1997) to determine the complementarity or redundancy of results. Correlation of RFLP and AFLP was determined by the NTSYS-PC option MXCOMP. A multiple correspondence analysis (MCA) was also generated, using the SAS option CORRESP (SAS, version $6,1989)$ to assess the relationships among strains and to evaluate the contribution of AFLP products to the variation observed among strains. The number of clusters generated by 
Table 1. Xam strains used in this study

\begin{tabular}{|c|c|c|c|c|c|}
\hline Strain* & $\begin{array}{l}\text { Colombian } \\
\text { department }\end{array}$ & Location & $\begin{array}{l}\text { Year of } \\
\text { isolation }\end{array}$ & $\mathrm{ECZ}+$ & Haplotype \\
\hline CIAT 1121 & Cauca & Mondomo & 1974 & 5 & $\mathrm{C} 8$ \\
\hline $\mathrm{CIO}-1$ & Meta & Carimagua & 1995 & 2 & $\mathrm{C} 1$ \\
\hline CIO-37 & Meta & Carimagua & 1995 & 2 & $\mathrm{C} 2$ \\
\hline $\mathrm{CIO}-4$ & Meta & Villavicencio & 1995 & 2 & $\mathrm{C} 3$ \\
\hline $\mathrm{CIO}-5$ & Meta & Villavicencio & 1995 & 2 & $\mathrm{C} 4$ \\
\hline CIO-81 & Magdalena & Pivijay & 1995 & 1 & $\mathrm{C} 5$ \\
\hline CIO-90 & Magdalena & Pivijay & 1995 & 1 & $\mathrm{C} 6$ \\
\hline CIO-11 & Cauca & Cajibío & 1995 & 5 & $\mathrm{C} 7$ \\
\hline CIO-12 & Cauca & Cajibío & 1995 & 5 & $\mathrm{C} 8$ \\
\hline $\mathrm{CIO}-22$ & Cauca & Cajibío & 1995 & 5 & $\mathrm{C} 9$ \\
\hline CIO-24 & Bolívar & María La Baja & 1995 & 1 & $\mathrm{C} 10$ \\
\hline CIO-25 & Bolívar & María La Baja & 1995 & 1 & C11 \\
\hline $\mathrm{CIO}-40$ & Meta & Villavicencio & 1995 & 2 & $\mathrm{C} 12$ \\
\hline $\mathrm{ClO}-46$ & Meta & Villavicencio & 1995 & 2 & C13 \\
\hline CIO-59 & Córdoba & La Corosa & 1995 & 1 & C14 \\
\hline $\mathrm{CIO}-62$ & Córdoba & La Corosa & 1995 & 1 & C15 \\
\hline CIO-64 & Sucre & Sincelejo & 1995 & 1 & C16 \\
\hline CIO-136 & Meta & Granada & 1995 & 2 & C17 \\
\hline CIO-84 & Magdalena & Pivijay & 1995 & 1 & C18 \\
\hline CIO-119 & Meta & Carimagua & 1995 & 2 & C19 \\
\hline CIO-151 & Meta & Granada & 1995 & 2 & $\mathrm{C} 20$ \\
\hline CIO-121 & Meta & Carimagua & 1995 & 2 & $\mathrm{C} 21$ \\
\hline CIO-33 & Meta & Carimagua & 1995 & 2 & $\mathrm{C} 22$ \\
\hline CIO-167 & Meta & Villavicencio & 1995 & 2 & $\mathrm{C} 23$ \\
\hline CIO- 168 & Meta & Villavicencio & 1995 & 2 & $\mathrm{C} 24$ \\
\hline CIO-171 & Meta & Villavicencio & 1995 & 2 & $\mathrm{C} 25$ \\
\hline CIO- 174 & Meta & Villavicencio & 1995 & 2 & $\mathrm{C} 26$ \\
\hline $\begin{array}{l}\mathrm{CIO}-298,299,300,301,302 \\
303,304,306,307,309\end{array}$ & Cauca & Mondomo & 1996 & 5 & $\mathrm{C} 8$ \\
\hline $\begin{array}{c}\mathrm{CIO}-378,379,381,382,385 \\
387,388,389,390,391 \$\end{array}$ & Cauca & Cajibío & 1996 & 5 & $\mathrm{C} 8$ \\
\hline
\end{tabular}

"CIAT, Xanthomonas collection, Centro Internacional de Agricultura Tropical; CIO, CIATORSTOM collection at Biotechnology Unit, CIAT, Cali, Colombia. All strains are field isolates except the reference strain CIAT 1121.

†ECZ: 1, subhumid tropics; 2, acid-soil savannas; 5, high-altitude tropics.

$\ddagger p t h \mathrm{~B}$ haplotypes as previously published (Restrepo \& Verdier, 1997) or as determined in this study. $\$$ RFLP analyses were performed on these ten strains. All procedures were identical to that previously described (Restrepo \& Verdier, 1997).

the MCA analysis was estimated by the cophenetic coefficient. A genetic diversity index $(\mathrm{Ht})$ was calculated for each cluster based on the band presence or absence. Ht represents the probability that two strains randomly chosen and belonging to the same cluster are different (Nei, 1973).

\section{RESULTS}

\section{Selection of AFLP enzymes and primers}

AFLP markers were assessed for their usefulness in characterizing molecular diversity among Xam strains. Six strains were analysed with all 64 possible $+1 /+1$ EcoRI/MseI, PstI/MseI, EcoRI/TaqI, PstI/TaqI primer combinations and the additional Pst I $+\mathrm{GG} / \mathrm{Mse} \mathrm{I}+\mathrm{G}$ combination. An analysis of the results showed that banding patterns obtained by using restriction enzymes with $\mathrm{G}+\mathrm{C}$-rich recognition sequences, such as TaqI (T $\downarrow$ CGA) and Pst I (CTGCA $\downarrow$ G), contained more bands than fingerprints generated with restriction enzymes with $\mathrm{A}+\mathrm{T}$-rich sequences, such as $\mathrm{Mse} \mathrm{I}(\mathrm{T} \downarrow \mathrm{TAA}$ ) and EcoRI (G $\downarrow$ AATTC) (Table 2). Fingerprints were also more complex when $\mathrm{G}$ or $\mathrm{C}$ was the selective base on the primers. For example, when Xam DNA was digested with PstI/TaqI and G was the selective base for the PstI primer in the first amplification, banding patterns were difficult to read because of the high number of bands. Replacing TaqI with MseI in the EcoRI/TaqI combination led to a threefold decrease in the number of bands. In general, bands appeared weak when A was the selective base for the PstI or EcoRI primers. Fingerprints 
(a)

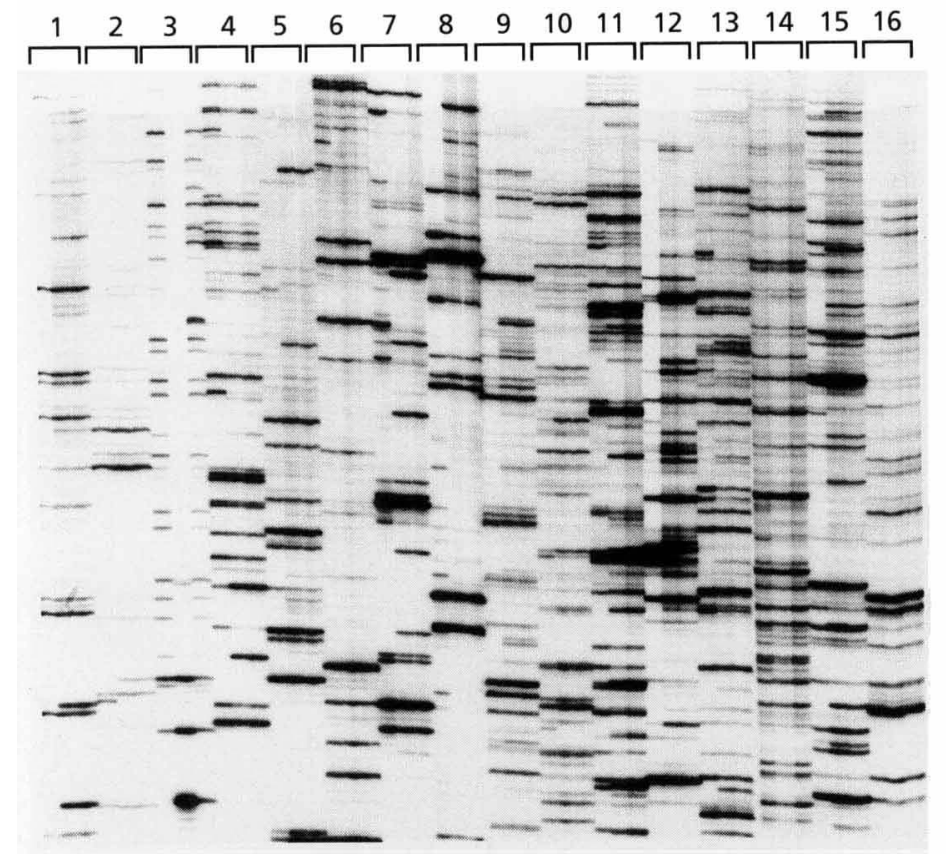

(b)

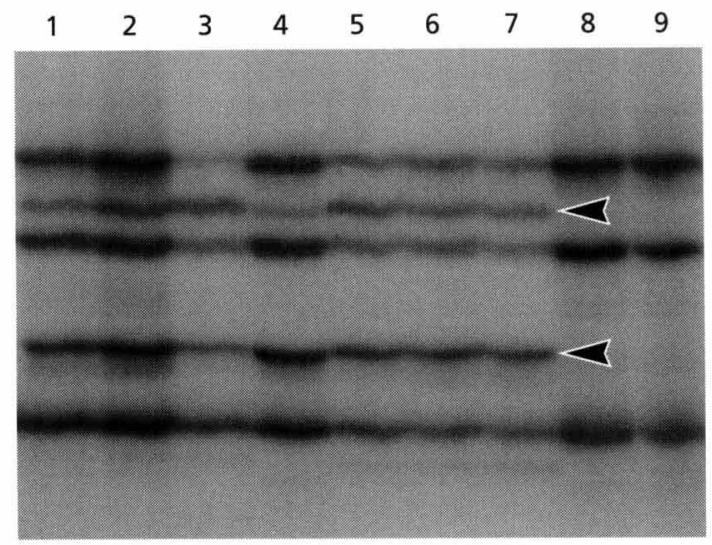

Fig. 1. (a) AFLP patterns of Xam, using 16 different $+1 /+1$ primer combinations. DNA templates were digested with ECORI/Taql and the same three strains were used for each primer combination: CIO-46 (ECZ2), CIO-299 (ECZ5) and CIO-300 (ECZ5). The primer combinations are (1) $+A /+A,(2)+A /+T,(3)+A /+C,(4)+A /+G,(5)+T /+A,(6)+T /+T,(7)+T /+C$,

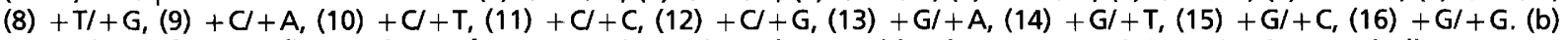
A section of AFLP fingerprints of Xam strains using the combination EcoRI $+T / M s e l+A$. Arrows indicate some polymorphic bands among ECZ5 strains. The strains are (1) ClAT-1121, (2) ClO-298, (3) CIO-299, (4) CIO-300, (5) ClO-301, (6) $\mathrm{ClO}-302,(7) \mathrm{ClO}-303,(8) \mathrm{ClO}-304,(9) \mathrm{ClO}-306$.

Table 2. Number of polymorphic bands out of total bands (shown in fraction form) obtained by AFLP analysis with 65 different primer combinations after digestion with EcoRl/Msel, Pstl/Msel, EcoRl/Taql and Pstl/Taql

The combinations shown in bold were selected for further analyses.

\begin{tabular}{|c|c|c|c|c|c|c|c|c|c|}
\hline \multirow[t]{2}{*}{ Enzyme } & \multirow[b]{2}{*}{ Base } & \multicolumn{4}{|c|}{ MseI } & \multicolumn{4}{|c|}{ TaqI } \\
\hline & & A & $\mathrm{T}$ & C & G & A & $\mathrm{T}$ & C & G \\
\hline \multirow[t]{4}{*}{ EcoRI } & A & -* & $-*$ & $4 / 15$ & $5 / 18$ & $5 / 27$ & $8 / 30$ & $4 / 41$ & $10 / 41$ \\
\hline & $\mathrm{T}$ & $21 / 36$ & $21 / 39$ & $3 / 19$ & $1 / 6$ & $7 / 23$ & $2 / 21$ & $11 / 26$ & $15 / 26$ \\
\hline & C & $6 / 17$ & $3 / 19$ & $1 / 20$ & $2 / 12$ & $13 / 47$ & $1 / 34$ & $13 / 64$ & $13 / 41$ \\
\hline & G & $5 / 11$ & $3 / 18$ & $3 / 14$ & $2 / 15$ & $14 / 45$ & $1 / 39$ & $16 / 50$ & $3 / 34$ \\
\hline \multirow{5}{*}{ Pst $\mathrm{I}$} & A & $-*$ & $-*$ & $-*$ & - & $-*$ & $-*$ & -4 & $-*$ \\
\hline & $\mathrm{T}$ & $13 / 27$ & $9 / 22$ & $11 / 26$ & $13 / 38$ & $15 / 31$ & - & $14 / 30$ & $11 / 28$ \\
\hline & C & $17 / 27$ & $13 / 25$ & $25 / 28$ & $20 / 39$ & $18 / 47$ & $-*$ & $21 / 28$ & $23 / 32$ \\
\hline & G & $14 / 60$ & $8 / 45$ & $13 / 50$ & $10 / 70$ & $-\dagger$ & $-\dagger$ & $-\dagger$ & $-\dagger$ \\
\hline & GG & $-\neq$ & $-\ddagger$ & $-\ddagger$ & $9 / 27$ & $-\ddagger$ & $-\ddagger$ & $-\ddagger$ & $-\ddagger$ \\
\hline
\end{tabular}

*Very few and weak bands.

† Not determined because of the complexity of banding patterns.

$\ddagger$ Not studied.

obtained with the primer combination PstI + GG/ $M s e I+G$ (27 bands) were less complex than those obtained with the combination Pst $\mathrm{I}+\mathrm{G} / \mathrm{Mse} \mathrm{I}+\mathrm{G}$ (70 bands). This result highlights the importance of carefully choosing the selective base composition of AFLP primers. Fig. 1(a) shows the influence of the selective 


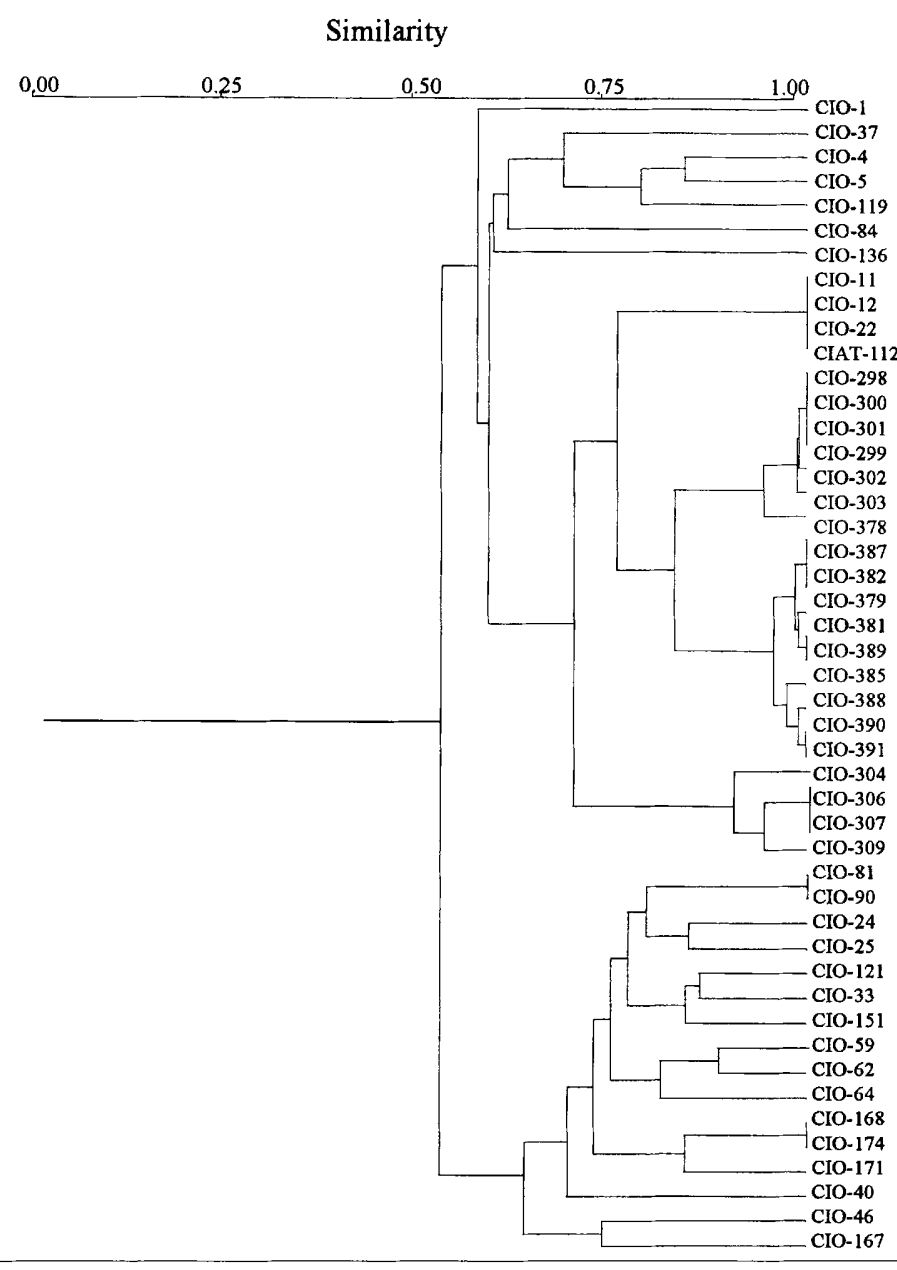

UPGMA

ECZ chuster

$$
\begin{aligned}
& \begin{array}{ll}
2 & 1 \\
2 & 2
\end{array} \\
& 2\} 3 \\
& 2\}^{3} \\
& \begin{array}{l}
4 \\
5
\end{array} \\
& \left.\begin{array}{l}
5 \\
5 \\
5
\end{array}\right) \\
& \begin{array}{l}
5 \\
5 \\
5
\end{array} \\
& 5 \\
& 5\} 6 \\
& 5 \\
& 5 \\
& 5 \\
& \begin{array}{l}
5 \\
5 \\
5
\end{array} \\
& 5 \\
& 5 \\
& \left.\begin{array}{l}
5 \\
5 \\
5 \\
5
\end{array}\right\} 7 \\
& 5 \\
& \left.\begin{array}{l}
5 \\
1 \\
1 \\
1
\end{array}\right) \\
& \begin{array}{l}
1 \\
1 \\
1
\end{array} \\
& \left.\begin{array}{l}
2 \\
2 \\
2
\end{array}\right\} 8 \\
& \text { \} } \\
& 1 \\
& 1 \\
& \begin{array}{l}
2 \\
2
\end{array} \\
& 2
\end{aligned}
$$

Fig. 2. Dendrogram of $47 \mathrm{Xam}$ strains based on AFLP analysis using the unweighted pair group arithmetic mean (UPGMA) program of NTSYS-PC (version 1.80; Rohlf, 1994). The ECZ and the UPGMA clusters are indicated. nucleotides added to the AFLP primers on fingerprint complexity, using EcoRI and TaqI.

In the preliminary trials to select successful primer combinations, polymorphic bands were found within strains collected in ECZ5 (Fig. 1b) that belong to the same $p t h \mathrm{~B}$ haplotype, a result that was not obtained with RFLP assays, even with the highly discriminative $p t h \mathrm{~B}$ probe. Polymorphic AFLP bands were also found between strains from ECZ5 and other ECZs. Eight primer combinations were selected according to reproducibility, percentage and number of polymorphic bands specific to strains from ECZ5, and polymorphism among ECZ5 strains. The combinations selected are shown in Table 2 . When testing the reproducibility of the results, less than $1 \%$ of the bands were evaluated differently. Therefore, the AFLP methodology gave highly reproducible bands.

\section{Cluster analysis}

Analysis of $47 \mathrm{Xam}$ strains presented a total of 322 AFLP bands from the eight primer combinations. Between 28 and 64 bands per strain were obtained, ranging from 40 to $350 \mathrm{bp}$. However, a high number of bands per primer combination were monomorphic. Consequently, we considered 173 bands ( $53 \%$ of total bands) for the MCA and cluster analyses.

When the 173 polymorphic AFLP bands were used for cluster analysis, different dendrograms were obtained because of ties occurring when the strains were assigned to a group. A strain which is equidistant to two clusters can be equally assigned to either one of these, and consequently the analysis can give different dendrograms. The dendrograms obtained were similar, with minor differences in the arrangement of the isolates collected in ECZ1 and ECZ2. The arrangement of the ECZ5 strains was identical in all dendrograms. Fig. 2 shows the dendrogram that had the highest cophenetic correlation coefficient $(r=0.95)$ to the similarity matrix. The cophenetic correlation coefficient measures the agreement between the similarity values implied by the dendrogram and those of the original similarity matrix (Sneath \& Sokal, 1973).

The set of 47 strains can be classified into 10 clusters using $70 \%$ similarity as a cut-off point (Fig. 2). We observed a general agreement between the ECZs from which the strains originated and nine of the clusters (Fig. 2). Clusters 6 and 7 consisted of strains from only ECZ5 beyond $71 \%$ similarity. Clusters 3 and 10 grouped few strains collected in ECZ2. Clusters 1, 2, 4, 5 and 9 each 
consisted of one strain only. Cluster 8 grouped strains originating from ECZs 1 and 2. However, strains within cluster 8 that were collected in the same ECZ showed about $75 \%$ similarity.

AFLP allowed the discrimination of closely related strains collected in ECZ5 (Fig. 1b). These strains were grouped into two separate clusters (Fig. 2): cluster 6, which grouped 21 strains collected in 1995 and 1996 in Cajibío and Mondomo, and cluster 7, which consisted of four strains collected in 1996 in Mondomo. Within cluster 6 , the location where strains were collected correlated with subclusters at $80 \%$ similarity. Both clusters formed by ECZ5 strains presented more than $68 \%$ similarity between them and less than $57 \%$ similarity with clusters grouping strains collected in ECZs 1 and 2.

\section{MCA}

The MCA performed on the set of $47 \mathrm{Xam}$ strains separated the strains into seven clusters (data not shown). The first three dimensions explained $47 \cdot 4 \%$ of the variation observed among strains. The first dimension explained $25 \%$ of the variation and was effective in separating ECZ5 strains from $X$ am strains collected in ECZs 1 and 2. Twenty different AFLP bands allowed the differentiation between ECZ5 strains. In general, a good correlation existed between unweighted pair group arithmetic mean clusters and MCA clusters. Moreover, MCA cluster 4 grouped strains from ECZ5 (unweighted pair group arithmetic mean cluster 6 and 7) and a strain (CIO-136) collected in ECZ2. The Ht was determined for each cluster, and was low for all clusters, which indicates a high level of similarity among strains belonging to the same cluster. The MCA also helped in identifying AFLP bands specific to the strains and thus significant for clustering of the strains.

\section{Comparison of the AFLP and RFLP data}

To determine the complementarity or redundancy of the information obtained for the same set of strains, using RFLP with the $p t h \mathrm{~B}$ probe and AFLP with eight primer combinations, similarity matrices based on RFLP and AFLP data were compared by correlation analysis. Matrices of genetic similarity estimates, based on both methods, were correlated $(r=0 \cdot 79)$. Fig. 3 depicts a two-way scattergram of similarities, obtained for each pair of strains and using RFLP or AFL.P as the molecular technique. The analysis of the scattergram showed that the results obtained by AFLP and RFLP are correlated but not redundant and that the AFLP technique was more informative than the RFLP for the same set of strains. When RFLP did not detect similarities (similarity $=0$ ), AFLP detected relationships ranking between $0 \cdot 3$ and 0.8 (Fig. 3). Furthermore, for those strains that showed the highest values of similarity with RFLP, AFLP established a similarity range from 0.6 to 1.0 and was better able to differentiate between the strains. AFLP showed identity for fewer cases and not all were

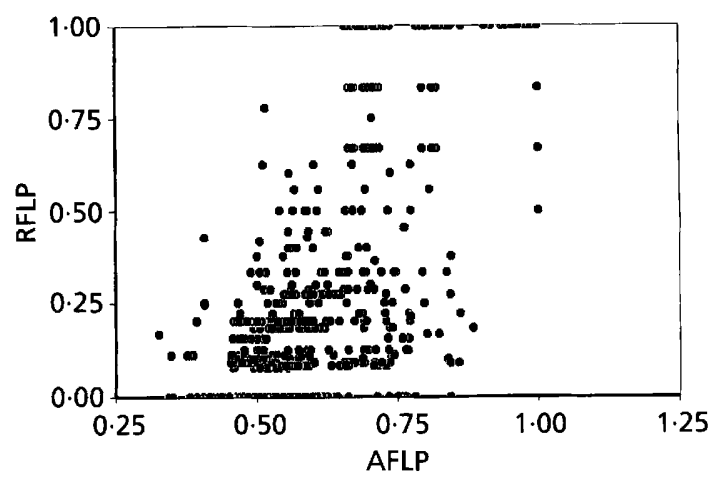

Fig. 3. Comparison of similarity matrices obtained by RFLP and AFLP analyses on 47 Xam strains, using MXCOMP, a matrix comparison program of NTSYS-PC (version 1.80; Rohlf, 1994). The axes represent similarity values.

confirmed by RFLP, that is, the results are not redundant.

\section{DISCUSSION}

AFLP is an extremely useful and reliable technique for detecting polymorphism in bacterial populations and its reproducibility is reportedly very high (Vos et al., 1995). A total of 173 polymorphisms were detected using eight combinations of selective primers. The use of a different set of restriction enzymes or of more or different primer combinations can dramatically increase the number of polymorphisms detected. Bacterial genomes are relatively small and, in general, one selective base for both primers yields scorable banding patterns (Janssen $e t$ al., 1996). A complex and informative fingerprint can thus become useful by making small changes in the primer sequence. The appropriate choice of restriction enzymes, and the number and base composition of selective bases, determine the usefulness and applicability of AFLP fingerprints in diversity studies.

The AFLP technique conditions and primer combinations that permit the assessment of Xam genetic diversity were established. We used three enzymes proposed by Janssen et al. (1996): EcoRI, TaqI and MseI. In Xam DNA, fragments obtained after digestion with EcoRI/TaqI were smaller than after digestion with Msel instead of TaqI. Janssen et al. (1996) also reported that in most eukaryotic DNAs, A+T-rich MseI produced much smaller restriction fragments than TaqI. Additionally, with Xam we demonstrated that the use of PstI generates fingerprints with an adequate number of suitably sized fragments. The use of a set of four enzymes and eight primer combinations (Table 2) is proposed as a standard set to characterize Xam. These combinations could be further tested for bacteria that belong to different pathovars of Xanthomonas axonopodis.

The efficiency of two techniques for measuring genetic diversity in Xam was compared: RFLP analysis, which is 
currently in use in Xam studies (Restrepo \& Verdier, 1997; Verdier et al., 1993), and AFLP. Bragard et al. (1997) and Valsangiocomo et al. (1995) demonstrated the concordance between results obtained by RFLP, using ribosomal or genomic probes, and AFLP in molecular typing of Xanthomonas translucens and Legionella pneumophila, respectively. Here, we show that results obtained from AFLP agree well with results obtained from RFLP, using the pathogenicity gene $p t h B$ as a probe (Restrepo \& Verdier, 1997); the AFLP data not only supported but also extended the RFLP/pthB analysis by revealing the existence of sub-groups among the ECZ5 Xam population. By having a superior discriminative power in differentiating highly related strains belonging to the same pathovar, AFLP analysis is a valuable alternative in Xam population studies.

Xam population ECZ5 is a homogeneous group of strains showing high levels of similarity. The low level of molecular variation among ECZ5 strains may be explained by two hypotheses: (i) the introduction of $X a m$ to this ecozone is recent and, most probably, only a few Xam strains were introduced through contaminated planting material from another ECZ; and (ii) homogeneity within the host population is reflected in the pathogen population. In this ecozone, the cassava varieties grown are few in number as a result of local preferences and production constraints limit the host's genetic base (Restrepo \& Verdier, 1997).

AFLP results support the hypothesis that strains from ECZ5 form a genetically and evolutionary separate group. Strong evidence exists to suggest that the pathogen migrates between and within ECZs in Colombia (Lozano, 1986; Restrepo \& Verdier, 1997), but because of the low similarity observed between ECZ5 strains and strains collected in other ECZs, the origin of the ECZ5 strains remains unclear. A further accurate analysis of ECZ5 strains and a study of their evolution are needed to understand the introduction of these strains to ECZ5.

Our study demonstrated that AFLP may be applied in Xam diversity studies, particularly for those populations where RFLP/pthB analyses present low levels of diversity. AFLP markers can also be used to identify particular races or pathotypes to monitor the dynamics of AFLP haplotypes within each region and deploy cassava varieties resistant to the pathogen. In addition to population studies, AFLP DNA fingerprinting may facilitate the identification of polymorphisms linked to virulence factors and contribute to the understanding of plant-bacteria interactions at the molecular level.

\section{ACKNOWLEDGEMENTS}

We gratefully acknowledge William Roca (CIAT) for his support. We are grateful to Martin Fregene and Fernando Angel for critically reading the manuscript. We thank Claude Bragard for his comments and advice on the first draft of the manuscript, and Elizabeth de Páez for editing. We are very grateful to Pedro Rocha for his helpful comments throughout this work and technical assistance. This research was supported by grants from ORSTOM and CIAT and by a doctoral fellowship awarded to S. Restrepo by ORSTOM.

\section{REFERENCES}

Berthier, Y., Verdier, V., Guesdon, J. L., Chevrier, D., Denis, J. B., Decoux, G. \& Lemattre, M. (1993). Characterization of Xanthomonas campestris pathovars by rRNA gene restriction patterns. Appl Environ Microbiol 59, 851-859.

Boucher, C., Barberis, P., Trigalet, A. \& Demery, D. (1985). Transposon mutagenesis of Pseudomonas solanacearum: isolation of Tn5-induced avirulent mutants. J Gen Microbiol 131, 2449-2457.

Bragard, C., Singer, E., Alizadeth, A., Vauterin, L., Maraite, H. \& Swings, J. (1997). Xanthomonas translucens from small grains: diversity and phytopathological relevance. Phytopathology 87, 1111-1117.

Dijkshoorn, L., Aucken, H., Gerner-Smidt, P., Janssen, P., Kaufmann, M. E., Garaizar, J., Ursing, J. \& Pitt, T. L. (1996). Comparison of outbreak and nonoutbreak Acinetobacter baumanii strains by genotypic and phenotypic methods. J Clin Microbiol 34, 1519-1525.

Folkerstma, R. T., Rouppe van der Voort, N. A. M., de Groot, K. E., van Zandvoort, P. M., Schots, A., Gommers, F. J., Helder, J. \& Bakker, J. (1996). Gene pool similarities of potato cyst nematode populations assessed by AFLP analysis. Mol Plant-Microbe Interact 9, 47-54.

Huys, G., Altwegg, M., Hanninen, M. L. \& 7 other authors (1996). Genotypic and chemotaxonomic description of two subgroups in the species Aeromonas eucrenophila and their affiliation to $A$. encheleia and Aeromonas DNA hybridization group 11. Syst Appl Microbiol 19, 616-623.

Janssen, P. \& Dijkshoorn, L. (1996). High resolution DNA fingerprint of Acinetobacter outbreak strains. FEMS Microbiol Lett 142, 191-194.

Janssen, P., Coopman, R., Huys, B., Swings, J., Bleeker, M., Vos, P., Zabeau, M. \& Kersters, K. (1996). Evaluation of the DNA fingerprinting method AFLP as a new tool to bacterial taxonomy. Microbiology 142, 1881-1893.

Leach, J. E., Rhoads, M. L., Vera Cruz, C. M., White, F. F., Mew, T. W. \& Leung, H. (1992). Assessment of genetic diversity and population structure of Xanthomonas oryzae pv. oryzae with a repetitive DNA element. Appl Environ Microbiol 58, 2188-2195.

Leung, H., Nelson, R. J. \& Leach, J. E. (1993). Population structure of plant pathogenic fungi and bacteria. Adv Plant Pathol 10, 157-205.

Lin, J. J., Kuo, J. \& Ma, J. (1996). A PCR-based DNA fingerprinting technique: AFLP for molecular typing of bacteria. Nucleic Acids Res 24, 3649-3650.

Louws, F. J., Fulbright, D. W., Stephens, C. T. \& de Bruijn, F. J. (1995). Differentiation of genomic structure by rep-PCR fingerprinting to rapidly classify Xanthomonas campestris pv. vesicatoria. Phytopathology 85, 528-536.

Lozano, J. C. (1986). Cassava bacterial blight: a manageable disease. Plant Dis 70, 1089-1093.

Maes, M., Garbeva, P. \& Kamoen, O. (1996). Recognition and detection in seed of the Xanthomonas pathogens that cause cereal leaf streak using rDNA spacer sequences and polymerase chain reaction. Phytopathology 86, 63-69.

Nei, M. (1973). Analysis of gene diversity in subdivided populations. Proc Natl Acad Sci 70, 3321-3323.

O’Neill, N. R., van Berkum, P., Lin, J. J., Kuo, J., Ude, G. N., 
Kenworthy, W. \& Saunders, J. A. (1997). Application of amplified restriction fragment length polymorphism for genetic characterization of Colletotrichum pathogens of alfalfa. Phytopathology 87, 745-750.

Picardeau, M., Prodhom, G., Raskine, L., Le-Pennec, M. P. \& Vincent, V. (1997). Genotypic characterization of five subspecies of Mycobacterium kansasii. J Clin Microbiol 35, 25-32.

Restrepo, S. \& Verdier, V. (1997). Geographical differentiation of the population of Xanthomonas axonopodis pv. manibotis in Colombia. Appl Environ Microbiol 63, 4427-4434.

Rohlf, F. J. (1994). NTSYS-PC: Numerical Taxonomy and Multivariate Analysis Syst, Version 1.80. New York: Exeter Software.

SAS Institute (1989). SAS/IML Software: Usage and Reference, Version 6, 1st edn. Cary, NC: SAS Institute.

Smith, J. J., Scott-Craig, J. S., Leadbetter, J. R., Bush, G. L., Roberts, D. L. \& Fulbright, D.W. (1994). Characterization of random amplified polymorphic DNA (RAPD) products from Xanthomonas campestris and some comments on the use of RAPD products in phylogenetic analysis. Mol Phylogenet Evol 3, $135-145$.
Sneath, P. H. A. \& Sokal, R. R. (1973). Numerical Taxonomy: The Principles and Practice of Numerical Classification. San Francisco: W. H. Freeman.

Valsangiocomo, C., Baggi, F., Gaia, V., Balmelli, T., Peduzzi, R. \& Piffaretti, J.-C. (1995). Use of amplified fragment length polymorphism in molecular typing of Legionella pneumophila and application to epidemiological studies. J Clin Microbiol 33, 1716-1719.

Vaneechoutte, M. (1996). DNA fingerprinting techniques for microorganisms: a proposal for classification and nomenclature. Mol Biotechnol 6, 115-142.

Verdier, V., Dongo, P. \& Boher, B. (1993). Assessment of genetic diversity among strains of Xanthomonas campestris pv. manihotis. J Gen Microbiol 139, 2591-2601.

Vos, P., Hogers, R., Bleeker, M. \& 8 other authors (1995). AFLP a new technique for DNA fingerprinting. Nucleic Acids Res 23, $4407-4414$.

Received 31 March 1998; revised 4 August 1998; accepted 16 September 1998. 